\section{Mustard Cover Crops Are Ineffective in Suppressing Soilborne Disease or Improving Processing Tomato Yield}

\author{
T.K. Hartz, P.R. Johnstone, E.M. Miyao, ${ }^{1}$ and R.M. Davis ${ }^{2}$ \\ Department of Plant Sciences, University of California, Davis, CA 95616
}

Additional index words. Brassica juncea, Sinapis alba, Verticillium dahliae, Fusarium, Lycopersicon esculentum, glucosinolate

\begin{abstract}
Mustard (Brassica spp.) cover crop residue has been reported to have significant 'biofumigant' action when incorporated into soil, potentially providing disease suppression and yield improvement for the succeeding crop. The effects of growing over-winter mustard cover crops preceding processing tomato (Lycopersicon escultentum Mill.) production were investigated in six field trials in the Sacramento Valley of California from 2002-04. A selection of mustard cover crops were compared to a legume cover crop mix, a fallow-bed treatment (the current grower practice in the region), and in two of the six trials, fumigation treatments using metam sodium. Mustard cover crops removed 115 to $350 \mathrm{~kg} \cdot \mathrm{ha}^{-1} \mathrm{~N}$ from the soil profile, reducing $\mathrm{NO}_{3}-\mathrm{N}$ leaching potential. Soil populations of Verticillium dahliae Kleb. and Fusarium spp. were unaffected by the cover crops, and there was no evidence of soilborne disease suppression on subsequent tomato crops. Mustard cover crops increased tomato yield in one field, and reduced yield in two fields. In one of two fields, metam sodium fumigation significantly increased tomato yield. We conclude that, while environmental benefits may be achieved, mustard cover cropping offers no immediate agronomic benefit for processing tomato production.
\end{abstract}

Processing tomato is an important crop in the Sacramento Valley of California, and the sustainability of tomato production from both an economic and environmental perspective has been the subject of considerable research. Between the Sustainable Agriculture Farming Systems (SAFS) (Clark et al., 1999) and the Long-term Research on Agricultural Systems (LTRAS) (Denison et al., 2004) projects there have been nearly 20 site-years comparing organic, reduced input, and conventional production practices. One feature of organic and reduced input systems that might be useful in conventional production is the use of over-winter cover crops; currently nearly all commercial fields in the region are maintained in a fallow condition before tomato production. In both the SAFS and LTRAS projects over-winter cover cropping improved soil physical and biological properties (Clark et al., 1998; Colla et al., 2000; Martini et al., 2003; Poudel et al., 2001); unfortunately, the direct effects of cover cropping on tomato yield were unclear, since other management differences (fertilizer, weed control, direct seeding vs. transplanting, etc.) among production systems were confounding factors. Miyao and Robbins (2000) evaluated cover cropping in conventionally managed Sacramento Valley tomato fields across three production seasons (1998-2000). In all years cover cropping significantly reduced winter runoff and increased tomato yield up to $7 \%$ compared with a winter fallow treatment. Although the factors responsible for yield

Received for publication 15 July 2005. Accepted for publication 29 Aug. 2005. We are indebted to the California Tomato Research Institute for financial support, and to J. Davis of the University of Idaho for technical support.

${ }^{1}$ University of California Cooperative Extension. ${ }^{2}$ Department of Plant Pathology. improvement were not identified, possible mechanisms included improved in-season irrigation water infiltration (Colla et al., 2000) or suppression of soilborne diseases (VanBruggen, 1995).

While cover crop evaluation in the SAFS and LTRAS projects centered on legumes due to their contribution to $\mathrm{N}$ fertility, the use of other types of cover crops may be more appropriate in conventional rotations where $\mathrm{N}$ availability is seldom a production constraint. Given their widely documented biofumigation effects (Brown and Morra, 1997; Fenwick et al., 1989), mustard cover crops (family Brassicaceae) present a potentially useful alternative. Mustards contain glucosinolates, compounds that upon hydrolysis release isothiocyanates (ITCs) and related compounds with broad biocidal activity. Among the soil pathogens reported to be effectively suppressed by the action of mustard residues are Verticillium dahliae (Olivier et al., 1999; Subbarao et al., 1999), Sclerotinia minor (Subbarao, 1998), and Helminthosporium solani (Vaughn et al., the effects of over-winter mustard cover crops on soil pathogen populations, disease expression and fruit yield in conventionally managed processing tomato rotations.

\section{Materials and Methods}

Field trials were conducted at the University of California-Davis (UCD) and in commercial fields in Yolo County, Calif., from 2002-04. At UCD in 2002 processing tomatoes were grown in a Yolo silt loam soil. Production practices typical of the local commercial industry were used. Following harvest in early September, crop residue was incorporated into the raised, 1.5 -m-wide beds, which were maintained so 1993). This study was conducted to evaluate that the existing buried drip irrigation system could be reused the following season. The following cover crops were seeded on 22 Nov: 1 ) 'Humus' (rape, Brassica napus L.); 2) 'Pacific Gold' [indian mustard, B. juncea (L.) Czern.]; 3) 'Ida Gold' (white mustard, Sinapis alba L.); 4) 'ISCI 20' (S. alba); and 5) a mixture of 'Lana' woolypod vetch (Vicia dasycarpa Ten.), 'Magnus' pea (Pisum sativum L.), and 'Cayuse' oat (Avena sativa L.). The cover crops were sown and lightly incorporated on the top of the raised beds. A fallow bed control treatment was also included to represent the typical over-winter management practice. The experimental design was randomized complete block, with four replications; individual plots were one bed wide $\times 30 \mathrm{~m}$ long.

Cover crops were germinated by precipitation and were allowed to grow undisturbed until 28 Mar. 2003, when above-ground biomass was determined. One representative $0.5-\mathrm{m}^{2}$ section per plot was harvested, and cover crop fresh and dry biomass recorded. On 31 Mar. cover crops were flail-mowed and immediately incorporated to a depth of about $15 \mathrm{~cm}$ with two passes of a bed disk. The field was left undisturbed until mid-May when the soil beds were fertilized at 20 and $25 \mathrm{~kg} \cdot \mathrm{ha}^{-1} \mathrm{~N}$ and $\mathrm{P}$, respectively. Tomato transplants ('Halley') were set in the field on 23 May. The crop was sprinkler-irrigated for establishment, then dripirrigated for the remainder of the season. An additional $165 \mathrm{~kg} \cdot \mathrm{ha}^{-1} \mathrm{~N}$ was applied through the drip system over the growing season. A destructive fruit harvest was made on $17 \mathrm{Sept}$, with total fruit yield determined; marketable yield was determined after the removal of cull (green, sunburned and rotten) fruit. Soluble solids concentration of marketable fruit ( ${ }^{\circ}$ Brix, by refractometer) was measured, and the soluble solids yield (marketable yield $\times{ }^{\circ}$ Brix, a measure of overall productivity) was calculated.

In Fall 2003, a second experiment was initiated at UCD. A field of Yolo silt loam in which processing tomatoes had been grown that summer was prepared for cover crop planting. Arandomized complete block design was used, with four replications of six treatments; individual plots were one $1.5-\mathrm{m}$ bed wide $\times 30 \mathrm{~m}$ long. The following cover crops were seeded on 6 Nov.: 1) 'Pacific Gold'; 2) 'Caliente' (a commercial blend of two separate cultivars, one B. juncea and one S. alba); and 3) vetch-pea-oat mixture. Additional treatments were a winter fallow, winter fallow plus springapplied metam sodium, and 'Pacific Gold' plus spring-applied metam sodium. The cover crops were sown on the bed tops and germinated by precipitation.

On 18 Mar. 2004, the cover crops were flail-mowed and immediately incorporated as described for the 2002-03 trial. The beds were then rolled and sprinkler-irrigated for 6 $\mathrm{h}$ to provide ideal conditions for hydrolysis of glucosinolates in the cover crop residue. Before incorporation, cover crop above-ground fresh and dry biomass was determined on a $0.6-\mathrm{m}^{2}$ section of each plot. Metam sodium (Soil Prep; Wilbur Ellis Co., San Francisco, Calif.) was applied to designated plots 1 week after cover 
crop incorporation, into soil near field capacity moisture content. The fumigant was applied through the buried drip irrigation system at $89 \mathrm{~kg} \cdot \mathrm{ha}^{-1}$ a.i. in $60 \mathrm{~m}^{3} \cdot \mathrm{ha}^{-1}$ of water. Preplant fertilizer was applied at 20 and $25 \mathrm{~kg} \cdot \mathrm{ha}^{-1} \mathrm{~N}$ and $\mathrm{P}$, respectively. 'Heinz 9665' transplants were planted in single rows per bed on 6 May. Irrigation and additional $\mathrm{N}$ fertilization were as described for the previous season. Adestructive fruit harvest was made on 31 Aug. Total and marketable fruit yield, and fruit soluble solids yield, were determined.

Four commercial field trials were initiated near Woodland, Calif., in Fall 2003; site characteristics and cultural details are given in Table 1. At one site (designated Woodland A) five overwintering treatments were compared: 1) 'Pacific Gold';2) 'Caliente'; 3) vetch-pea-bell bean (Vicia faba L. var. equina) mixture; 4) winter fallow; and 5) winter fallow + springapplied metam sodium. The experimental design was randomized complete block with 6 replications; individual plots were three beds wide $\times 45 \mathrm{~m}$ long. Cover crops were seeded 6 Nov. and incorporated 16 Mar. 2004. Cover crop biomass was determined on $1-\mathrm{m}^{2}$ sections of the middle bed of each plot before incorporation; biomass of the $B$. juncea and $S$. alba components of the 'Caliente' blend were evaluated separately. Cover crops were flail-mowed and immediately incorporated with a bed disc. One week after incorporation metam sodium was applied at $107 \mathrm{~kg} \cdot \mathrm{ha}^{-1}$ a.i. in designated plots by a tractor-mounted applicator through four injection shanks per bed.

In the remaining fields (designated Woodland B, C, and D), fall-seeded 'Caliente' blend was compared to fallow bed management. At these sites the experimental design was randomized complete block, with 10,8 , and 5 replications, respectively; individual plots were 3 beds wide by 30 to $45 \mathrm{~m}$ long. Mustard biomass was determined as at Woodland A. Mustard plots were flail-mowed and incorporated by disking within $30 \mathrm{~min}$. At commercial maturity, all Woodland field trials were machine harvested; total and marketable fruit yield and fruit soluble solids yield were determined.

Glucosinolate concentration of aboveground mustard biomass was determined for all 2003-04 trials except Woodland C. Immediately before soil incorporation, five to six representative whole plants were collected from each of three plots of each type of mustard cover crop; for the 'Caliente' blend, B. juncea and $S$. alba plants were collected and analyzed separately. The plants were freeze-dried and ground to pass through a 1-mm mesh screen. Concentrations of the primary glucosinolates (benzyl, 2-propenyl, 2-phenylethyl, 2-hydroxy-3-butenyl, and 4-hydroxybenzyl) were determined by gas chromatography using a modification of the procedure of Daun and McGregor (1991).

Net N mineralization rate from 2003-04 cover crop residues was evaluated in a laboratory incubation. Oven-dried cover crop samples were ground and analyzed for total $\mathrm{N}$ content by combustion (Carlo Erba 1500; Fisons Instruments, Beverly, Mass.). Soil from the UCD site was wetted to field capacity. Ground residue from each cover crop type from each site was blended into the moist soil at $0.5 \%$ by dry weight. Three replicate subsamples of moist, unamended soil, and of each residue/soil blend, were extracted in $2 \mathrm{~N} \mathrm{KCl}$ and analyzed for mineral $\mathrm{N}$ concentration $\left(\mathrm{NO}_{3}-\mathrm{N}+\mathrm{NH}_{4}-\mathrm{N}\right)$ using a flow injection analyzer (Lachat Instruments, Milwaukee, Wis.). The remainder of the unamended moist soil and the soil-residue blends were incubated in sealed containers at $20^{\circ} \mathrm{C}$; the containers were vented weekly to maintain aerobic conditions. After four weeks triplicate samples of unamended soil and of each soil-residue blend were extracted in $2 \mathrm{~N}$ $\mathrm{KCl}$ for determination of mineral $\mathrm{N}$ concentration. The change in mineral $\mathrm{N}$, adjusted for the change in unamended soil, represented net $\mathrm{N}$ mineralization or immobilization by the residue.

The effect of cover crops on soilborne pathogens was evaluated at four of the 2003-04 trial sites. At UCD and Woodland A soil samples were collected in Fall 2003, before cover crop planting, and again in Spring 2004, before transplanting tomatoes. In each plot a composite sample of 12 soil cores ( 0 to 15 $\mathrm{cm}$ deep) was collected. After the sample was homogenized, a 3-g sample was added to 30 $\mathrm{mL}$ of $0.1 \%$ water agar. Following agitation for $5 \mathrm{~min}$, two aliquots of $1 \mathrm{~mL}$ each were plated on selective media (pectate agar for Verticillium dahliae and Komada's medium for Fusarium spp.). Depending on the concentration of propagules in the soil, dilutions were adjusted to achieve a visually manageable number of colonies on the plates. Colonies of $V$. dahliae and Fusarium spp. were counted with the aid of a dissecting microscope. Soil pathogen data were analyzed by the ANCOVA procedure (SAS Institute, Cary, N.C.) using soil pathogen population preceding cover crop production as the covariate in the analysis of the spring populations.

During the 2004 tomato season significant foliar expression of plant infection by $V$. dahliae (Woodland A), fusarium foot rot (Fusarium solani) (Woodland $\mathrm{B}$ ), and fusarium wilt ( $F$. oxysporum f.sp. lycopersici W.C. Snyder \& H.N. Hans.) (Woodland C) were observed. At each site the number of plants exhibiting disease symptoms was recorded 4 to 6 weeks before harvest. The identity of each pathogen was confirmed by plating symptomatic tissue on water agar or potato-dextrose agar.

\section{Results}

Mustard cover crops produced high biomass at UCD and the Woodland A and C sites, with much less biomass at Woodland $\mathrm{B}$ and

Table 1. Site characteristics and cultural details of the 2003-04 commercial cover crop trials.

\begin{tabular}{lcccc}
\hline & \multicolumn{3}{c}{ Site } \\
\cline { 2 - 5 } & Woodland A & Woodland B & Woodland C & Woodland D \\
\hline Soil texture & Silt loam & Fine sandy loam & Silty clay loam & Silt loam \\
2003 summer crop & Tomato & Wheat & Tomato & Tomato \\
Cover crop seeding date & 6 Nov. & 14 Nov. & 19 Nov. & 21 Nov. \\
Cover crop incorporation date & 16 Mar. & 14 Mar. & 18 Mar. & 23 March \\
Tomato cultivar & Heinz 9780 & PS 347 & Heinz 9780 & HM 849 \\
Transplanting date & 16 Apr. & 9 Apr. & 21 May & 11 May \\
Tomato harvest date & 23 Aug. & 30 Aug. & Crop loss & 15 Sept. \\
\hline
\end{tabular}

D (Table 2). Where it was grown, the legume mix had substantially lower biomass than any mustard, undoubtedly due to the relatively early incorporation dates used. With the exception of the Woodland B site (following wheat), all 2003-04 mustard cover crops had high tissue $\mathrm{N}$ concentration. Above-ground biomass N ranged from $115 \mathrm{~kg} \cdot \mathrm{ha}^{-1}$ ('Caliente' at Woodland B) to $350 \mathrm{~kg} \cdot \mathrm{ha}^{-1}$ ('Pacific Gold' at Woodland A). Fertilization of the mustard cover crops was done only at Woodland B $\left(60 \mathrm{~kg} \cdot \mathrm{ha}^{-1} \mathrm{~N}\right)$; elsewhere, mustard biomass $\mathrm{N}$ represented uptake of residual and mineralized soil N. The low-N 'Caliente' residue from Woodland B showed net $\mathrm{N}$ immobilization over 4 weeks of incubation, equivalent to about 6 $\mathrm{kg} \cdot \mathrm{ha}^{-1} \mathrm{~N}$; in that field a seasonal total of 160 $\mathrm{kg} \cdot \mathrm{ha}^{-1} \mathrm{~N}$ was applied to the tomato crop, an amount sufficiently in excess of normal fertilizer requirement (Krusekopf et al., 2002) to overcome any adverse effect of cover crop immobilization. All other samples showed substantial net $\mathrm{N}$ mineralization, averaging about $20 \%$ of $\mathrm{N}$ content. The $\mathrm{N}$ concentration of cover crop residue was positively correlated with net $\mathrm{N}$ mineralization rate $(r=0.76)$.

Tissue glucosinolate concentration varied among sites and between mustard cultivars, averaging $16 \mathrm{mmol} \cdot \mathrm{kg}^{-1}$ dry tissue (Table 2). $B$. juncea tissue contained mostly 2-propenyl glucosinolate, while the benzyl and 4-hydroxybenzyl forms were predominate in $S$. alba tissue. Total above-ground glucosinolate content of mustard residues ranged from 75 to $153 \mathrm{~mol} \cdot \mathrm{ha}^{-1}$.

Cover crops had no significant suppressive effects on soil populations of $V$. dahliae or Fusarium spp. In Spring 2004, Verticillium populations varied from 4 to 14 colony forming units (cfu)/g at UCD and 11 to $24 \mathrm{cfu} / \mathrm{gat}$ Woodland A. Fusarium populations ranged from 4,000 to $5,700 \mathrm{cfu} / \mathrm{g}$ at UCD and 3,200 to $4,100 \mathrm{cfu} / \mathrm{g}$ at Woodland A. No significant foliar expression of soilborne disease was observed at UCD in 2004, or at Woodland D. At Woodland A the percent of plants showing foliar symptoms of $V$. dahliae infection was unaffected by cover crops; only the metam sodium treatment showed significant reduction in foliar symptoms (Table 3). At Woodland B Fusarium foot rot incidence was not significantly reduced by the cover crop. At Woodland Cincorporation of 'Caliente' residue resulted in a significant increase in the percentage of plants showing foliar symptoms of Fusarium wilt; by harvest this disease had killed most plants in both the cover crop and fallow treatments, precluding fruit yield measurement.

At UCD cover crops had no significant effect on tomato fruit yield or soluble solids 
Table 2. Above-ground cover crop biomass, nitrogen concentration, net nitrogen mineralization, and glucosinolate content; parentheses indicate standard errors.

\begin{tabular}{|c|c|c|c|c|c|c|c|}
\hline \multirow{2}{*}{$\frac{\text { Year }}{2002-03}$} & \multirow[b]{2}{*}{ Site } & \multirow[b]{2}{*}{ Cover crop } & \multirow{2}{*}{$\begin{array}{l}\text { Dry biomass } \\
\left(\mathrm{Mg} \cdot \mathrm{ha}^{-1}\right)\end{array}$} & \multirow{2}{*}{$\begin{array}{c}\mathrm{N} \\
\left(\mathrm{g} \cdot \mathrm{kg}^{-1}\right)\end{array}$} & \multirow{2}{*}{$\begin{array}{c}\mathrm{N} \\
\text { mineralization }(\%)^{\mathrm{z}}\end{array}$} & \multicolumn{2}{|c|}{ Total glucosinolates } \\
\hline & & & & & & $\overline{\left(\mathrm{mmol} \cdot \mathrm{kg}^{-1}\right)}$ & $\left(\mathrm{mol} \cdot \mathrm{ha}^{-1}\right)$ \\
\hline & UCD & Pacific Gold & $7.0(0.5)$ & & & & \\
\hline & UCD & ISCI 20 & $9.2(0.9)$ & & & & \\
\hline & UCD & Legume mix & $3.8(0.6)$ & & & & \\
\hline 2003-04 & $\mathrm{UCD}$ & Pacific Gold & $6.7(0.6)$ & 40 & $23(4)$ & $17(4)$ & $113(29)$ \\
\hline & UCD & Caliente $^{\mathrm{y}}$ & $8.2(0.4)$ & 33 & $13(3)$ & $16(3)$ & $129(24)$ \\
\hline & Woodland A & Caliente & $9.9(0.3)$ & 31 & $7(1)$ & $16(1)$ & $153(2)$ \\
\hline & Woodland A & Legume mix & $5.2(0.4)$ & 37 & $25(1)$ & & \\
\hline & Woodland B & Caliente & $6.0(0.2)$ & 23 & $-5(2)$ & $13(1)$ & $75(5)$ \\
\hline & Woodland C & Caliente & $8.1(0.2)$ & 41 & $9(4)$ & & \\
\hline & Woodland D & Caliente & $4.7(0.2)$ & 46 & $19(1)$ & $24(3)$ & $113(12)$ \\
\hline
\end{tabular}

${ }^{2}$ Percent of biomass $\mathrm{N}$ mineralized in 4 weeks of soil incubation at $20^{\circ} \mathrm{C}$; negative number indicates net immobilization.

${ }^{y}$ Brassica juncea and Sinapis alba portions analyzed separately at all sites; data presented are weighted means.

Table 3. Incidence of foliar symptoms of soilborne disease, 2003-04 commercial trials.

\begin{tabular}{lccc}
\hline Site & $\begin{array}{c}\text { Over-winter } \\
\text { field treatment }\end{array}$ & Disease & $\begin{array}{c}\text { Foliar symptoms } \\
\text { (\% of plants) }\end{array}$ \\
\hline Woodland A & Fallow & Verticillium wilt & $41 \mathrm{a}$ \\
& Fallow + metam sodium & & $19 \mathrm{~b}$ \\
& Pacific Gold & & $37 \mathrm{a}$ \\
Caliente & Legume mix & & $46 \mathrm{a}$ \\
Woodland B & Fallow & Fusarium foot rot & $42 \mathrm{a}$ \\
& Caliente & & 21 \\
Woodland C & & & 16 \\
& Fallow & Fusarium wilt & $52 \mathrm{~b}$ \\
\hline
\end{tabular}

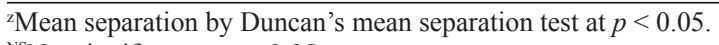

NSNonsignificant at $p<0.05$.

Table 4. Effect of over-winter field treatment and spring-applied metam sodium on yield of tomato fruit, and fruit soluble solids.

\begin{tabular}{|c|c|c|c|c|}
\hline \multirow[b]{2}{*}{ Site } & \multirow{2}{*}{$\begin{array}{l}\text { Over-winter } \\
\text { field treatment }\end{array}$} & \multicolumn{2}{|c|}{ Fruit yield $\left({\left.\mathrm{Mg} \cdot h a^{-1}\right)}\right.$} & \multirow{2}{*}{$\begin{array}{c}\text { Fruit solids }^{2} \\
\left(\mathrm{Mg} \cdot \mathrm{ha}^{-1}\right)\end{array}$} \\
\hline & & Total & Marketable & \\
\hline \multirow[t]{7}{*}{$\overline{\text { UCD 2002-03 }}$} & Fallow & 113 & 102 & 5.25 \\
\hline & Pacific Gold & 106 & 95 & 5.02 \\
\hline & Ida Gold & 105 & 94 & 5.08 \\
\hline & ISCI 20 & 107 & 95 & 5.14 \\
\hline & Humus & 106 & 96 & 5.01 \\
\hline & Legume mix & 111 & 100 & 5.16 \\
\hline & & NS & NS & NS \\
\hline \multirow[t]{7}{*}{ UCD 2003-04 } & Fallow & 122 & 110 & 5.27 \\
\hline & Fallow + metam sodium & 126 & 117 & 5.67 \\
\hline & Pacific Gold & 110 & 101 & 5.09 \\
\hline & Pacific Gold + metam sodium & 117 & 108 & 5.29 \\
\hline & Caliente & 110 & 104 & 5.09 \\
\hline & Legume mixture & 122 & 110 & 5.24 \\
\hline & & NS & NS & NS \\
\hline \multirow[t]{5}{*}{ Woodland A } & Fallow & $144 b^{y}$ & $121 \mathrm{~b}$ & $5.58 \mathrm{ab}$ \\
\hline & Fallow + metam sodium & $153 \mathrm{a}$ & $131 \mathrm{a}$ & $5.69 \mathrm{a}$ \\
\hline & Pacific Gold & $134 \mathrm{c}$ & $109 \mathrm{~cd}$ & $5.12 \mathrm{~cd}$ \\
\hline & Caliente & $129 \mathrm{c}$ & $106 \mathrm{~d}$ & $5.00 \mathrm{~d}$ \\
\hline & Legume mix & $136 \mathrm{c}$ & $114 \mathrm{c}$ & $5.35 \mathrm{bc}$ \\
\hline \multirow[t]{3}{*}{ Woodland B } & Fallow & $137 \mathrm{a}$ & 117 & 5.42 \\
\hline & Caliente & $124 \mathrm{~b}$ & 108 & 5.24 \\
\hline & & & NS & NS \\
\hline \multirow[t]{3}{*}{ Woodland D } & Fallow & 143 & $116 \mathrm{~b}$ & 4.90 \\
\hline & Caliente & 153 & $123 \mathrm{a}$ & 5.21 \\
\hline & & NS & & NS \\
\hline
\end{tabular}

${ }^{\mathrm{z}}$ Marketable yield $\times$ soluble solids concentration $\left({ }^{\circ} \mathrm{Brix}\right)$

${ }^{y}$ Mean separation within sites by Duncan's mean separation test at $p<0.05$.

NSNonsignificant at $p<0.05$.

yield in either year (Table 4). In 2004, metam sodium, alone or in combination with 'Pacific Gold', was similarly ineffective at UCD. However, at Woodland A, metam sodium significantly increased both total and marketable yield compared to the winter fallow treatment, which in turn had higher yield than any cover crop treatment. Both mustard cover crops had lower soluble solids yield than either the fallow or metam sodium treatments. Yield reduction with cover crops may have been due in part to damaging populations of darkling ground beetles (Blapstinus spp.), which were concentrated primarily in cover crop plots; chemical treatment and limited replacement of damaged transplants in those plots was necessary. Also, the grower established the transplants with irrigation through a buried drip irrigation system. At transplanting, soil moisture in cover crop plots was lower than in fallow plots, the result of cover crop transpiration during spring growth; differences in early season water availability may have affected tomato growth in cover crop plots.

Total fruit yield at Woodland B was significantly lower in 'Caliente' plots compared to the fallow treatment. The opposite result was observed at Woodland D, where 'Caliente' production resulted in increased marketable tomato yield. No fruit yield was obtained at Woodland C, where Fusarium wilt resulted in a complete crop loss.

\section{Discussion:}

In six field trials the use of over-wintering mustard cover crops had no consistent effects on soilborne disease suppression or tomato fruit productivity. The lack of effective disease suppression may have been attributable to several factors: insufficient glucosinolate content in the residue, incomplete conversion of glucosinolates to ITCs, or inefficient field management practices that reduced biofumigation effectiveness. While tissue glucosinolate concentrations were similar to those reported elsewhere (Lazzeri et al., 2003; Morra and Kirkegaard, 2002), and the amount of mustard biomass achieved at most of the sites was substantial, total glucosinolate content of the mustard residues was very low in comparison to typical application rates of synthetic fumigants like metam sodium. The metam sodium treatments used at UCD and Woodland A contained 690 and $830 \mathrm{~mol} \cdot \mathrm{ha}^{-1}$ of ITC-forming compounds, respectively, or 5 to 11 times the molar equivalent glucosinolate content of mustard residues at those sites. Since the toxicity of different ITCs varies widely (Sarwar et al., 1998) a direct molar comparison is simplistic; however, the relatively small 
amount of glucosinolate contained in mustard residues suggested a practical limitation to their effectiveness in disease suppression. Given the wide genotypic variation in glucosinolate concentration among mustard cultivars (Kirkegaard and Sarwar, 1998), further selection and breeding may significantly increase glucosinolate content of field-grown mustard cover crops.

Perhaps more important than total glucosinolate content of mustard residues are the factors governing release, distribution and retention of ITCs in the soil following residue incorporation. ITC release from mustard tissues requires hydrolysis of glucosinolates by myrosinase (Brown and Morra, 1997); since myrosinase and glucosinolates are separated in intact mustard tissues, the degree of tissue maceration during cover crop incorporation can greatly affect ITC formation. Morra and Kirkegaard (2002) reported that no more than $1 \%$ of ITC predicted from tissue glucosinolate concentration was measured in soil amended with mustard leaf tissue; cellular disruption by freezing and thawing increased ITC release efficiency, but to no more than $26 \%$. Once mustard tissue is macerated, ITC release is rapid. Brown et al. (1991) reported that ITC concentration reached a maximum only $2 \mathrm{~h}$ after soil incorporation, and declined by $>90 \%$ within $24 \mathrm{~h}$. Lazzeri et al. (2004) found that $40 \%$ or more of initial glucosinolate content was lost if tissue was allowed to dry.

These factors suggest that grower management of mustard residues could greatly affect biofumigation effectiveness. For maximum effect, mustard residues need to be thoroughly shredded and immediately incorporated into moist soil. To the extent practical, those practices were followed in these field trials; in all fields the cover crops were flail-mowed and incorporated within $<1 \mathrm{~h}$. To prevent soil compaction the growers were forced to schedule these operations when the soil was drier than field capacity moisture content, potentially allowing some tissue desiccation. At UCD in 2004 sprinkler irrigation was applied immediately after incorporation to minimize this problem. Yet even with these efforts to optimize practices, no significant biofumigation effects were observed in any field.

Other researchers have reported that fieldgrown Brassica crops effectively suppressed soilborne disease in succeeding crops, increasing crop productivity. Examples include take-all (Gaeumannomyces graminis) on wheat (Kirkegaard et al, 2000), sclerotinia drop (Sclerotinia minor) on lettuce (Hao and Subbarao, 2003), and verticillium wilt (Verticillium dahliae) on cauliflower (Subbarao et al., 1999). In each of these studies, however, it was unclear whether ITC release from Brassica tissue was the primary mechanism of disease suppression, or whether more complex biological interactions were responsible.

Disease suppression is not the only potential benefit of cover crop production. Improved soil structure and water infiltration, and reduced winter runoff and associated erosion and nutrient loss, have been documented (Colla et al., 2000; Dabney et al., 2001; Joyce et al., 2002; Miyao and Robbins, 2000). In the present study large quantities of $\mathrm{N}$ were removed from the soil profile, decreasing $\mathrm{NO}_{3}-\mathrm{N}$ leaching potential. We conclude that mustard cover crops may provide environmental benefits but are unlikely to suppress soilborne pathogens or increase processing tomato productivity under representative field conditions in the Sacramento Valley.

\section{Literature Cited}

Brown, P.D. and M.J. Morra. 1997. Control of soilborne plant pests using glucosinolate-containing plants. Adv. Agron. 61:167-231.

Brown, P.D., M.J. Morra, J.P. McCafferey, D.L. Auld, and D.L. Williams. 1991. Allelochemicals produced during glucosinolate degradation in soil. J. Chem. Ecol. 17:2021-2034.

Clark, S., K. Klonsky, P. Livingston, and S. Temple. 1999. Crop yield and economic comparisons of organic, low-input, and conventional farming systems in California's Sacramento Valley. Amer. J. Alt. Agr. 14(3):109-121.

Clark, M.S., W.R. Horwath, C. Shennan, and K.M. Scow. 1998. Changes in soil chemical properties resulting from organic and low-input farming practices. Agron. J. 90:662-671.

Colla, G., J.P. Mitchell, B.A. Joyce, L.M. Huyuk, W.W. Wallender, S.R. Tempe, T.C. Hsaio, and D.D. Poudel. 2000. Soil physical properties, tomato yield and quality in alternative cropping systems. Agron. J. 92:924-932.

Dabney, S.M., J.A. Delgado, and D.W. Reeves. 2001. Using winter cover crops to improve soil and water quality. Commun. Soil Sci. Plant Anal. 32:1221-1250.

Daun, J.K. and D.I. McGregor. 1991. Glucosinolates in Seeds and Residues, p. 185-225. In: J.B. Rossell and J.L.R. Pritchard (eds.). Analysis of oilseeds, fats and fatty foods. Elsevier Publ., New York.

Denison, R.F., D.C. Bryant, and T.E. Kearney. 2004 Crop yields over the first nine years of LTRAS, a long-term comparison of field crop systems in a Mediterranean climate. Field Crops Res. $86: 267-277$

Fenwick, G.R., R.K. Heaney, and R. Mawson. 1989. Glucosinolates, p. 97-141. In: P.R. Cheeke (ed.). Toxicants of plant origin. vol 2. Glucosinolates. CRC Press, Boca Raton, Fla.

Hao, J. and K.V. Subbarao. 2003. Effects of broccoli rotation on lettuce drop caused by Sclerotinia minor and on the population density of sclerotia in soil. Plant Dis. 87:159-166.
Joyce, B.A.,W.W. Wallender, J.P. Mitchell,L. Huyck, S. Temple, P. Brostrom, and T. Hsaio. 2002. Infiltration and soil water storage under winter cover cropping in California's Sacramento Valley. Trans. Amer. Soc. Agr. Eng. 45:315-326.

Kirkegaard, J.A., M. Sarwar, P.T.W. Wong,A. Mead, G. Howe, and M. Newell. 2000. Field studies on the biofumigation of take-all by Brassica break crops. Austral. J. Agr. Res. 51:445-456.

Kirkegaard, J.A. and M. Sarwar. 1998. Biofumigation potential of brassica. I. Variation in glucosinolate profiles of diverse field-grown brassicas. Plant Soil 201:71-89.

Krusekopf, H.H., J.P. Mitchell, T.K. Hartz, D.M. May, E.M. Miyao, and M.D. Cahn. 2002. Presidedress soil nitrate testing identifies processing tomato fields not requiring sidedress $\mathrm{N}$ fertilizer. HortScience 37:520-524.

Lazzeri, L., O. Leoni, and L.M. Manici. 2004. Biocidal plant dried pellets for biofumigation. Ind. Crops Prod. 20:59-65.

Lazzeri, L., G. Baruzzi, L. Malaguti, and L. Antoniacci. 2003. Replacing methyl bromide in annual strawberry production with glucosinolate-containing green manure crops. Pest Mgt. Sci. 59:983-990

Martini, E.A., J.S. Buyer, D.C. Bryant, T.K. Hartz, and R.F. Dension. 2003. Yield increases during organic transition: Improving soil quality or increasing experience? Field Crops Res. $86: 255-266$.

Miyao, G. and P. Robins. 2000. Influence of fallplanted cover crops on rainfall run-off in a processing tomato production system. Acta Hort. 542:343-345.

Morra, M.J. and J.A. Kirkegaard. 2002. Isothiocyanate release from soil-incorporated Brassica tissues. Soil Biol. Biochem. 34:1683-1690.

Olivier, C., S.F. Vaughn, E.S.G. Mizubuti, and R. Loria. 1999. Variation in the allyl isothiocyanate production within Brassica species and correlation with fungicidal activity. J. Chem. Ecol. 25:2687-2701

Poudel, D.D., H. Ferris, K. Klonsky, W.R. Horwath, K.M. Scow, A.H.C. vanBruggen, W.T. Lanini, J.P. Mitchell, and S.R. Temple. 2001. The sustainable agriculture farming system project in California's Sacramento Valley. Outlook Agr. 30(2):109-116.

Sarwar, M., J.A. Kirkegaard, P.T.W. Wong, and J.M. Desmarchelier. 1998. Biofumigation potential of brassicas. III. In vitro toxicity of isothiocyanates to soilborne fungal pathogens. Plant Soil 201:103-112.

Subbarao, K.V. 1998. Progress toward integrated management of lettuce drop. Plant Dis 82:1068-1078.

Subbarao, K.V., J.C. Hubbard, and S.T. Koike. 1999. Evaluation of broccoli residue incorporation into field soil for verticillium wilt control in cauliflower. Plant Dis. 83:124-129.

VanBruggen, A.H.C. 1995. Plant disease severity in high-input compared to reduced-input and organic farming systems. Plant Dis. 79:976-984.

Vaughn, S.F., G.F. Spencer, and R. Loria. 1993. Inhibition of Helminthosporium solani strains by natural isothiocyanates. Amer. Potato J. $70: 852-853$. 